\title{
Quaternary ammonium "tannate" for antifouling coatings
}

\author{
Natalia Bellotti, Beatriz del Amo, and Roberto Romagnoli
}

Ind. Eng. Chem. Res., Just Accepted Manuscript • DOI: 10.1021/ie301524r • Publication Date (Web): 03 Dec 2012

Downloaded from http://pubs.acs.org on December 10, 2012

\section{Just Accepted}

"Just Accepted" manuscripts have been peer-reviewed and accepted for publication. They are posted online prior to technical editing, formatting for publication and author proofing. The American Chemical Society provides "Just Accepted" as a free service to the research community to expedite the dissemination of scientific material as soon as possible after acceptance. "Just Accepted" manuscripts appear in full in PDF format accompanied by an HTML abstract. "Just Accepted" manuscripts have been fully peer reviewed, but should not be considered the official version of record. They are accessible to all readers and citable by the Digital Object Identifier (DOI®). "Just Accepted" is an optional service offered to authors. Therefore, the "Just Accepted" Web site may not include all articles that will be published in the journal. After a manuscript is technically edited and formatted, it will be removed from the "Just Accepted" Web site and published as an ASAP article. Note that technical editing may introduce minor changes to the manuscript text and/or graphics which could affect content, and all legal disclaimers and ethical guidelines that apply to the journal pertain. ACS cannot be held responsible for errors or consequences arising from the use of information contained in these "Just Accepted" manuscripts.

\section{ACS Publications}




\author{
Quaternary ammonium "tannate" for antifouling coatings \\ Natalia Bellotti ${ }^{*}$, Beatriz del Amo², Roberto Romagnoli ${ }^{2,3}$ \\ ${ }^{1}$ ANPCyT, Fellow Researcher, ${ }^{2}$ CONICET Researcher, ${ }^{3}$ UNLP Professor \\ CIDEPINT Centro de Investigación y Desarrollo en Tecnología de Pinturas (CIC-CONICET) \\ Calle 52 e/ 121 y 122. (B1900AYB) La Plata. Argentina. FAX: 54-221-427 1537 \\ *E-mail: pinturashigienicas@cidepint.gov.ar
}

\begin{abstract}
The undesirable accumulation of a wide variety of marine organisms (biofouling) on ship hulls can lead to significant increased costs, principally by increased fuel consumption to maintain cruising speed. Generally, these coatings have bioactive compounds, called biocides.

In this sense, this paper deals with the assessment of the antifouling properties of a natural product derivative obtained from "quebracho" tannin and a quaternary ammonium salt (hexadecyltrimethylammonium bromide $\left(\left[\mathrm{CH}_{3}\left(\mathrm{CH}_{2}\right)_{15} \mathrm{~N}\left(\mathrm{CH}_{3}\right)_{3}\right] \mathrm{Br}\right)$. Two derivatives were obtained depending on the precipitation $\mathrm{pH}$ (4 and 8). The bioactivity of these derivatives was assessed by means of the Artemia larvae test. Furthermore, soluble matrix paints were prepared with two different binders: rosin / oleic acid and rosin / styrene-acrylate copolymer. The leaching of "quebracho" tannin derivatives from coatings in artificial sea water was monitored until obtain constant values, previous to the immersion in natural environments. Finally, the antifouling activity of coatings pigmented with the "quebracho" tannin derivative was evaluated in Mar del Plata harbor (38 $\left.08^{\prime} 17^{\prime \prime} \mathrm{S}-57^{\circ} 31^{\prime} 18^{\prime \prime} \mathrm{W}\right)$. The coating obtained with the derivative obtained at $\mathrm{pH} 4$ and rosin / oleic acid as binder proved to have an acceptable efficiency for ten months.
\end{abstract}

Keywords: antifouling coatings, tannin, quaternary ammonium salt, biocide activity, leaching rate. 


\section{Introduction}

The settlement and growth of marine organisms such as algae, barnacles, mussels, polychaetes, ascidians, bryozoans, etc., on hard substrates, is a global problem causing blockage of pipes and filtration systems as well as economic losses in ships due to the increasing fuel consumption ${ }^{1,2}$. Since ancient times, different strategies have been developed to prevent fouling on submerged structures and extend materials service life ${ }^{3}$. Coatings are worldwide used to avoid fouling settlement by incorporating biocides in their formulations. There are biocides free antifouling commercial coatings formulated with polysiloxanes whose action is due to the low energy surface they develop with concomitant low levels of adhesion ${ }^{4}$. The major disadvantage of this technology is that its use is restricted to high speed vessels ${ }^{5}$. The most widespread protective systems are based on self-polishing copolymer with $\mathrm{Cu}_{2} \mathrm{O}$ and organic biocides (Irgarol 1051, Diuron, Seanine, etc.) or conventional soluble matrix paints with the same biocides but with rosin or some of its derivatives as binders ${ }^{1,3,6}$. Taking in to account that rosin dissolution rate could be high, it is usually blended with cobinders or plasticizers (oils or other resins) to obtain suitable solubility and good mechanical properties. These coatings do not ensure protection for more than 12-18 months, because of the constant erosion they undergo during their service life $\mathrm{f}^{3,7}$.

The replacement of these biocides by more environment friendly ones is a matter of great interest to avoid their accumulation, principally in coastal areas ${ }^{6,8,9}$. They may also affect the development of marine organisms especially at the most vulnerable larval state ${ }^{6,10}$. The employment of quaternary ammonium salts in environmental-friendly coatings to control marine biofouling has been reported in recent years ${ }^{11,12}$. The approach in these researches were generally tethering quaternary ammonium salts to a polysiloxane matrix, the results mostly showed inhibition in the development of the biofilm ${ }^{11,12}$. 
The aim of this work is to obtain two quaternary ammonium "tannates" precipitating them from "quebracho" tannin and hexadecyltrimethylammonium bromide at two different $\mathrm{pH}, 4$ and 8, respectively. "Quebracho" is a native argentine tree with a high content of condensed tannin easily extractable by hot water ${ }^{13,14}$. This type of tannins contain natural polyphenols composed of flavanol units that can react with metallic cation $\left(\mathrm{Cu}^{2+}, \mathrm{Al}^{3+}, \mathrm{Zn}^{2+}\right)$ yielding the precipitation of the corresponding tannates. Tannin and tannates proved to possess antifouling activity ${ }^{15,16,17,18}$. The quaternary ammonium salt is a cationic surfactant and the quaternary ammonium groups act as antimicrobial agents because most bacterial cell walls are negatively charged. The bactericidal action involves the destructive interaction with the cell wall and/or the cytoplasmic membrane ${ }^{19}$.

The new derivatives obtained from quaternary ammonium salt and "quebracho" tannin were characterized in relation to their bioactivity with Artemia larvae. The tests with Artemia nauplii have the advantage of their rapidity and low cost as well as a good predictive potential; as a consequence, they constitute a valid alternative to tests with other crustacean species like barnacles (Balanus amphitrite) ${ }^{20,21}$. Then, antifouling coatings, with a soluble matrix and the quaternary ammonium "tannates" as biocide, were formulated ${ }^{18,22,23}$. The tannin leaching rate of these coatings in artificial sea water ${ }^{24}$ was determined by spectrophotometry using the Folin-Denis's reagent ${ }^{25,26,27}$. Finally, their biocidal activity was assessed in natural sea water and qualified according to ASTM D 3623 - 78a and ASTM D6990-0 $05^{28,29}$.

\section{Materials and Methods}

\subsection{Precipitation curves}

The chemical structures of quaternary ammonium salt and "quebracho" tannin are shown in Figure $1 \mathrm{a}-\mathrm{b}$. In order to optimize the preparation of quaternary ammonium salts, a 
precipitation curve was obtained at $\mathrm{pH} 4$ and $\mathrm{pH} 8$ respectively. Different suspensions containing $3.000 \mathrm{~g}$ of "quebracho" tannin dispersed in distilled water during 10 minutes were prepared and, then, $1.00,2.00,5.00$ and $10.00 \mathrm{ml}$, respectively, of $0,34 \mathrm{M}$ quaternary ammonium salt were mixed to the tannin suspensions. Distilled water was added to match a final volume of $25.0 \mathrm{ml}$. After the addition of QAS, the suspensions were stirred for 5 minutes and the $\mathrm{pH}$ adjusted to 4.0 or 8.0 using $0.5 \mathrm{M} \mathrm{NaOH}$. The suspensions were stirred during 1 hour more, $\mathrm{pH}$ was adjusted again and the systems were allowed to settle down for 24 hours to accomplish complete flocculation. Finally, an additional $\mathrm{pH}$ adjustment was carried out under stirring and the solids were separated by centrifugation and dried at $50 \pm 5^{\circ} \mathrm{C}$ until constant weight.

\subsection{Preparation of quaternary ammonium "tannate"}

Both quaternary ammonium "tannates", precipitated at pH 4 and 8 (QAT4 and QAT8 respectively), were prepared taking into account the suitable ratio of reactants according to the results obtained from the analysis of the precipitation curve. In this sense, $100 \mathrm{~g}$ of "quebracho" tannin were dispersed in $0.7 \mathrm{~L}$ of distilled water and $166.7 \mathrm{~mL}$ of $0.34 \mathrm{M}$ quaternary ammonium salt was added under constant stirring to precipitate QAT4. Immediately, $\mathrm{pH}$ was adjusted to 4.0 using a $0.5 \mathrm{M} \mathrm{NaOH}$ and the suspension was stirred during lhour. The suspension was kept overnight without stirring and $\mathrm{pH}$ was adjusted once more before separating the solids from the supernatants. The solids were washed with distilled water by decantation, centrifuged, dried at room temperature with the aid of an air current and, finally, in a stove at $50 \pm 5^{\circ} \mathrm{C}$.

In the case of QAT8, the procedure was similar but $160.0 \mathrm{~g}$ of tannin was dispersed in $0.8 \mathrm{~L}$ of distilled water and $533.3 \mathrm{~mL}$ of $0.34 \mathrm{M}$ QAS was added; the $\mathrm{pH}$ value was adjusted to 8.0 with $0.5 \mathrm{M} \mathrm{NaOH}$. 


\subsection{Characterization}

The fourier transform infrared spectroscopy (FTIR) spectrum of "quebracho" tannin, quaternary ammonium salt and the both quaternary ammonium "tannates" were obtained using the potassium bromide disc technique and a Perkin-Elmer Spectrum One FTIR Spectrometer. The density of the pigment, needed for coating formulation, was determined according to a standardized procedure ${ }^{30}$.

The solubility of the both quaternary ammonium "tannates" in artificial sea water was determined as described in a previously published $\operatorname{paper}^{18}$. The concentration of tannin was obtained spectrophotometrically at $750 \mathrm{~nm}$ using Folin-Denis's reagent and it was expressed as $\mathrm{mg} / \mathrm{L}$ of total polyphenols. This wavelength corresponds to the maximum of the so-called "molybdenum blue" compound obtained due to the reducing ability of $\operatorname{tannin}^{31}$.

\subsection{Bioassay}

The concentration to kills $50 \%$ of the Artemia nauplii population within 24 hours $\left(\mathrm{LC}_{50}\right)$ was determined using a short term toxicity test ${ }^{32}$.

Artemia persimilis eggs, commercially available, were hatched in artificial sea water at $22 \pm 2^{\circ} \mathrm{C}$ during 24 hours, under gentle aeration with an aquarium pump ${ }^{32}$. After 48 hours a homogenous population of instar II-III nauplii were obtained and used for the test. Saturated solutions of QAT4 and QAT8 were diluted adequately with artificial sea water to prepare two sets of different solutions containing 144, 288, 576, 768, $1152 \mathrm{ppm}$ and 50, 100, 200, 401ppm of total polyphenols respectively. Ten nauplii were placed in a vessel with $10 \mathrm{ml}$ of the respective quaternary ammonium "tannates" diluted solution and in a vessel with artificial sea water which was used as control. Copper sulfate was used as a positive control being the concentrations of the testing solutions 1.0, 10.0, 50.0, 100 and 200ppm respectively. Three 
replicates were set up for each concentration, including the controls. After an incubation period of $24 \mathrm{~h}$, dead larvae were counted and $\mathrm{LC}_{50}$ values were calculated by Probit analysis ${ }^{33}$.

\subsection{Formulation and preparation of coatings}

To formulate soluble matrix based antifouling paints, previous publications were considered ${ }^{18,22,23}$. Paints composition can be seen in Table 1 . The coatings A, B, D and E formulated to carry out this research contained WW rosin (Cicloquímica) as film forming material. The rosin was provided by Cicloquímica, $85-90 \%$ of its composition was resin acids among which the abietic and levopimaric acid were the most important (Figure 2 a-b respectively).

Rosin is a brittle solid (glass transition temperature about $30^{\circ} \mathrm{C}$ ) obtained from the exudation of pine and fir trees. It is usually classified according to its colour. The water white (WW) variety is commonly used to formulate antifouling paints ${ }^{34,35}$.

Oleic acid was employed as plasticizer. Zinc oxide was added to coatings B and E because zinc ions react with rosin to form resinates which are less soluble in seawater, thus reducing the binder dissolution rate ${ }^{35,36}$. The amount of $\mathrm{ZnO}$ added is approximately 12-25 time lower than that employed in commercial ones so called "biocide-free" commercial antifouling coatings ${ }^{6}$. On the other hand taking into account the concernsarisen about the use of $\mathrm{ZnO}$, other alternatives for replacing it in future works are under study ${ }^{6}$.

The respective "tannates" were dispersed in a fraction of the solvent (xylene/white spirit 4/1) in a ball mill jar (3.31) during 24 hours. Then, the vehicle and the chalk were incorporated into the jar and the dispersion was continued for other 24 hours. After this, castor oil gel was dispersed into the paint to act as a rheological additive. It is composed of several fatty acids: $89.5 \%$ recinolenic acid, $4.2 \%$ linolenic acid, $3.0 \%$ oleic acid, $1.0 \%$ stearic acid, $1.0 \%$ palmitic acid, $0.7 \%$ dihydroxystearic acid, $0.3 \%$ linolenic acid and $0.3 \%$ eicosanoic 
acid. Castor oil was previously swollen with xylene (15\% by weight), using a shear stress at $40-45^{\circ} \mathrm{C}$, until a stable colloidal structure was obtained.

Since QAT4 resulted more soluble that QAT8, it was necessary to formulate other coating with a co-binder. Therefore, coating C was prepared with QAT4 and styrene-acrylate copolymer plasticized as co-binder (Table 1). Styrene-acrylate copolymer is not soluble in artificial sea water, as a consequence it increases the resistance of coatings immersed in natural sea water, reducing its dissolution rate.

\subsection{Determination of leached polyphenols in artificial sea water}

Coatings were brush applied on $8 \times 8 \mathrm{~cm}$ sandblasted acrylic panels. Three or four coats of each coating were applied and allowed to dry 24 hours between each application. The total dry film thickness was $120 \pm 5 \mu \mathrm{m}$. Not more than 48 hours elapsed for the painted panels to be submerged in plastic containers containing $150 \mathrm{ml}$ of artificial sea water. The leached "tannate" was determined on a $2 \mathrm{ml}$ aliquot using the Folin-Denis's reagent. The original level of the liquid in the containers was restored periodically with distilled water and the $\mathrm{pH}$ was adjusted to 8.2 .

\subsection{Essays in natural sea water}

In this case, sandblasted acrylic panels $(8 \times 12 \mathrm{~cm})$ were coated as described before to a total dry film thickness of $180 \pm 5 \mu \mathrm{m}$. No more than 48 hours elapsed before the painted panels were immersed in a natural sea environment at Mar del Plata harbor in Argentina $\left(38^{\circ} 08^{\prime} 17^{\prime \prime} \mathrm{S}-57^{\circ} 31^{\prime} 18^{\prime \prime} \mathrm{W}\right)$. The coastal area where the trial was performed is subjected, predominantly, to atmospheric thermal cycling. The seawater temperatures exhibited seasonality with an average maximum of $20^{\circ} \mathrm{C}$ during February and a minimum of $9.3^{\circ} \mathrm{C}$ during July. The salinity ranged between 32.6 and 34.6 o/oo. 
Panels were immersed $50-60 \mathrm{~cm}$ deep and biofouling resistance was evaluated according to ASTM D 3623 - 78a and ASTM D6990-05. The range used for the fouling rating (FR) was from 0 to 100 . The FR for coatings free of adherent biofouling settlement was recorded as 100 . The rating of the AF efficiency of the coating was obtained by discounting from 100 the percentage of the area covered by macrofouling. A coating free of macrofouling settlement, but with adherent slime (microorganisms such as bacteria, fungi, diatoms and protozoa), was recorded with a $\mathrm{FR}=99$, whichever of the percentage of the covered area was. Therefore, fouling rating reflects non-fouled area. Distance smaller than $1 \mathrm{~cm}$ from the edge of the panels were not considered. Uncoated panels were used as control and immersed in the same conditions as the painted ones. Organisms such as barnacles, serpulids, ascidians, bryozoans, algae and polychaetes are frequent in Mar del Plata harbor and may be found attached onto the panels ${ }^{37,38}$. This assay was conducted in triplicate.

\section{Results and Discussion}

\subsection{Preparation and characterization of quaternary ammonium "tannates"}

The analysis of the precipitation curve revealed that the flocculation of tannin could be achieved with a quaternary ammonium cation (Figure 3). Practically, curves corresponding to QAT4 and QAT8 presented two different regions characterized by their slopes. The amount of precipitated tannin at both $\mathrm{pH}$ conditions, for a given amount of quaternary ammonium salt, increased faster at the beginning of the experiment. As a consequence, it was decided to carry out the precipitation of both "tannates" employing 0.20 and $0.40 \mathrm{~g}$ of quaternary ammonium salt per $\mathrm{g}$ of tannin at $\mathrm{pH}=4.0$ and 8.0 , respectively.

The density of QAT4 and QAT8 were 1.49 and $1.25 \mathrm{~g} / \mathrm{cm}^{3}$, respectively. The concentration of total polyphenols in the saturated solution of QAT4 in artificial sea water, 
obtained by spectrophotometry with the Folin-Denis's reagent, was found to be equal to 1152 and that of QAT8 401ppm.

FTIR spectra showed that both, "quebracho" tannin and quaternary ammonium "tannates", had a broad intense band around 3000-3600 $\mathrm{cm}^{-1}$ which corresponds to the stretching of the $\mathrm{OH}$ group (Figure 4). This band broadening was attributed to a larger number of hydrogen bonds ${ }^{39}$. Two bands appeared at 2930 and $2850 \mathrm{~cm}^{-1}$ in QAT4 and QAT8 spectra which correspond to the ammonium band ${ }^{39}$. In the case of quaternary ammonium salt, there are also some other bands (3020, 1490 and 1408) which could be assigned to the ammonium group $^{40}$. This fact proved that the reaction between quaternary ammonium salt and “quebracho" tannin has taken place.

Both "quebracho" tannin and its derivatives have an important band at $1620 \mathrm{~cm}^{-1}$ that could be assigned to the $\mathrm{C}=\mathrm{C} \operatorname{stretch}^{39,40}$. The spectra of QT and both derivatives shown two bands centered at 1520 and $1453 \mathrm{~cm}^{-1}$ due to the stretching of $\mathrm{C}=\mathrm{C}$ bond of the aromatic ring. The sharp band at $\sim 1230 \mathrm{~cm}^{-1}$ corresponds to the $\mathrm{C}-\mathrm{O}$ bond of phenols and the band next to $1080 \mathrm{~cm}^{-1}$ corresponds to the vibration of C-O bond ${ }^{40,41}$.

\subsection{Bioassays}

After an incubation period of $24 \mathrm{~h} \mathrm{LC}_{50}$ for QAT4 was found to be $958 \pm 57 \mathrm{mg} / 1$ and $7 \pm$ $2.0 \mathrm{mg} / \mathrm{l}$ was determined for copper sulfate (positive control), respectively. In the case of QAT8, no $\mathrm{LC}_{50}$ could be determined after $24 \mathrm{~h}$. These results showed that only QAT4 have some activity against Artemia persimili larvae; however its toxicity is much lower than that of copper sulphate.

\subsection{Determination of leached polyphenols as a function of time}


In these systems the reproducibility is acceptable and the variation coefficient between measurements was $\sim 4 \%$. The amount of tannin, measured as TP, leached from coatings with the higher solubility of QAT4 (coatings A, B and C) than that from coatings with QAT8 (coatings D and E, Figure 5). These results correlated with the major solubility of QAT4 in artificial sea water. Considering the leaching rate at a given interval of time, the highest values were measured for coatings $\mathrm{A}$ and $\mathrm{C}$ (Figure 6); however, during the first week of testing, leaching rate of coatings A, B and C decreased sharply. After the second week, the average leaching rate of the coatings $\mathrm{A}$ and $\mathrm{C}$ oscillated around $3.5 \mu \mathrm{g} . \mathrm{cm}^{-2}$.day ${ }^{-1}$. Therefore the incorporation of SAC did not alter too much the PT leaching rate from the immersed film. Coating formulated with QAT8 exhibited lower leaching rates from the beginning of the test. Coatings D and E presented an average leaching rate $\sim 1 \mu \mathrm{g} . \mathrm{cm}^{-2}$.day ${ }^{-1}$ after the first days of testing.

\subsection{Essays in natural sea water}

The selection of the coatings immersed in natural sea water, at Mar del Plata harbor, was conducted taking into account the results of preliminary laboratory test. Therefore, coating A, B and C were chosen because QAT4 proved to be active against Artemia larvae and, in addition, the average leaching rate were for these coatings $\left(3.5 \mu \mathrm{g} . \mathrm{cm}^{-2}\right.$.day $\left.{ }^{-1}\right)$ was higher than those of coatings D and E. According to previous results, the leaching rate of coatings $\mathrm{A}, \mathrm{B}$ and $\mathrm{C}$, must be considered adequate to performer immersion test in natural sea water $^{18,36}$.

Coated panels submerged in natural sea water were observed periodically. Controls showed increased fouling settlement with a FR $=10$ after the first month of immersion (Figure 7). Mostly ascidians, bryozoans, serpulids and algae were found attached onto coated panels. Coating A exhibited a high AF efficiency $(F R=100)$ during the first month if 
compared with the control panels $(\mathrm{FR}=0)$; but after the fourth month of exposition coating $\mathrm{A}$ showed a high wear and therefore, panels were removed from the test site. Coating B resulted to be the most efficient one with a $F R=95$ after eighth month which descended to 80 when ten months of immersion elapsed, keeping complete film integrity. However, at the year of immersion FR decreased sensibly. The use of styrene-acrylate copolymer in coating C allowed to increase film resistance due to its insoluble nature, extending its service life with respect to coating A. FR was 65 after eighth month with preserved film integrity. According to these results, it was necessary to decrease the leaching rate of coating A to extend its $\mathrm{AF}$ efficiency; this was accomplished by modifying the paint formulation.

\section{CONCLUSIONS}

Two different derivatives, QAT4 and QAT8, were obtained from ammonium salt and "quebracho" tannin by changing the precipitation pH. QAT4, in contrast with QAT8 showed to be active against Artemia larvae. Preliminary tests (bioassay and leaching rate determination) proved to be useful to select the most suitable coatings (A, B and C) to perform the immersion test in natural sea water at Mar del Plata harbor.

Coating $\mathrm{B}$ had longer service life than coatings $\mathrm{A}$ and $\mathrm{C}$, with a fouling rating above 80 until the tenth month of immersion. Therefore, the decreased leaching rate of the coating B relative to coatings $\mathrm{A}$ and $\mathrm{C}$ increased its service life, diminishing, at the same time, the wearing of the coating. The use of styrene-acrylate copolymer on coating $\mathrm{C}$, allowed to increase the film resistance extending its service life with respect to coating A. After 8 months of immersion antifouling efficiency decreased but film integrity was preserved.

\section{Acknowledgments}

The authors wish to thank to Consejo Nacional de Investigaciones Científicas y Técnicas (CONICET), Comisión de Investigaciones Científicas de la Provincia de Buenos 
Aires (CICPBA), Agencia Nacional de Promoción Científica y Tecnológica (ANPCyT) and the Universidad Nacional de La Plata (UNLP) for the support to do this research. They also thank to Gastón Guzmán for the analytical determinations.

\section{REFERENCES}

(1) Almeida, E.; Diamantino, T.C.; de Sousa, O. Marine paints: the particular case of antifouling paints. Prog. Org. Coat. 2007, 59, 2.

(2) Schultz, M.P., Effects of Coating Roughness and Biofouling on Ship Resistance and Powering. Biofouling. 2007, 23, 331.

(3) Yebra, D.M.; Kiil, S.; Dam-Johansen, K. Antifouling technology—past, present and future steps towards efficient and environmentally friendly antifouling coatings. Prog. Org. Coat. 2004, 50, 75 .

(4) Townsin, R.L.; Anderson, C.D. Fouling control coatings using low surface energy, foul release technology; Woodhead Publishimg Limited, CRC: UK, 2009.

(5) Callow, M.E.; Callow, J.A. Advances in marine antifouling coatings and technologies; Publishimg Limited, CRC: UK, 2009.

(6) Ytreberg, E.; Karlsson, J.; Eklund, B. Comparison of toxicity and release rates of Cu and $\mathrm{Zn}$ from anti-fouling paints leached in natural and artificial brackish seawater. Sien. Total Environ. 2010, 408, 2459.

(7) Chambers, L.D.; Stokes, K.R.; Walsh, F.C.; Wood, R.J.K. Modern approaches to marine antifouling coatings. Surf. Coat. Tech. 2006, 201, 3642.

(8) Konstantinou, I.K.; Albanis, T.A. Worldwide occurrence and effects of antifouling paint booster biocides in the aquatic environment: a review. Environ. Internat. 2004, 30, 235.

(9) Konstantinou, I.K. Antifouling Paint Biocides: Springer: New York, 2006.

(10) Nriagu, J.O. Cinc in the environmenta, Part 1: Ecological Cycling; Wiley-Interscience Publication: USA, 1980.

(11) Majumdar, P.; Lee, E.; Patel, N.; Ward, K.; Stafslien, S.J.; Daniels, J.; Chisholm, B.J.; Boudjouk, P.; Callow, M.E.; Callow, J.A.; Thompson, S.E. Combinatorial materials research applied to the development of new surface coatings IX: an investigation of novel 
antifouling/fouling-release coatings containing quaternary ammonium salt groups. Biofouling. 2008, 24, 185.

(12) Ye, S.; Majumdar, P.; Chisholm, B.; Stafslien, S.; Chen, Z. Antifouling and antimicrobial mechanism of tethered quaternaryammonium salts in a cross-linked poly(dimethylsiloxane) matrix studied using sum frequency generation vibrational spectroscopy. J. Surf. Coll. 2010, $26,16455$.

(13) Haslam, E. Chemistry of vegetable tannins; 2nd ed. Academic Press: London, 1966.

(14) Scalbert, A. Antimicrobial properties of tannins. Photochemistry. 1991, 30, 3875.

(15) Stupak, M.; García, M.; Pérez, M. Non-toxic alternative compounds for marine antifouling paints. Int. Biodet. Biodegran. 2003, 52, 49.

(16) Pérez, M.; Blustein, G.; García, M.; del Amo, B.; Stupak, M. Cupric tannate: A low copper content antifouling pigment. Prog. Org. Coat. 2006, 55, 311.

(17) Pérez, M.; García, M.; Blustein, G.; Stupak, M. Tannin and tannate from the quebracho tree: an eco-friendly alternative for controlling marine biofouling. Biofouling. 2007, 23, 151.

(18) Bellotti, N.; Deyá, C.; del Amo, B.; Romagnoli, R. Antifouling Paints with Zinc “Tannate". Ind Eng Chem.Res. 2010, 49, 3386.

(19) Kenawy, E.R.; Abdel-Hay, F.I.; El-Shanshoury, A.E.R.R.; El-Newehy, M.H. Biologically active polymers. V. Synthesis and antimicrobial activity of modified poly(glycidyl methacrylate-co-2-hydroxyethylmethacrylate) derivatives with quaternary ammonium and phosphonium salts. J.Polvm. Sci.Part A Polvm.Chem. 2002, 40, 2384.

(20) Vetere, V.; Pérez, M.; García, M.; Deyá, M.; Stupak, M.; del Amo, B. A non-toxic antifouling compound for marine paints. Surf. Coat. Int. 1999, 12, 386.

(21) Persoone, G.; Wells, P.G. Artemia Research and its Applications. Vol.1. Morphology, Genetics, Strain characterization, Toxicology; University Press: Belgium, 1987.

(22) Del Amo, B.; Giúdice, C.A.; Sindoni, O. High build soluble matrix antifouling paints based on vinyl resin. Prog. Org. Coat. 1989, 17, 287.

(23) Del Amo, B.; Giúdice, C. A.; Villoria, G. Antifouling paints of high sea water dissolution rate. Eur. Coat. J. 1990, 1, 8.

(24) ASTM D 1141-98. Standard practice for the preparation of substitute ocean water; ASTM international: USA, 2008. 
(25) Ferreira, E.; Nogueira, A.; Souza, G.; Batista, L. Effect of drying method and length of storage on tannin and total phenol concentrations in pigeon pea seeds. Food Chem. 2004, 86, 17.

(26) Dominy, N.; Davoust, E.; Minekus, M. Adaptive function of soil consumption: an in vitro study modeling the human stomach and small intestine. L.Exp.Biol. 2004, 207, 319.

(27) Erdemoğlu, S.B.M; Gücer, Ş. Selective determination of aluminum bound with tannin in tea infusion. Anal. Scien. 2005, 21, 1005.

(28) ASTM D 3623 - 78a. Standard test method for testing antifouling panels in shallow submergence; ASTM international: USA, 2004.

(29) ASTM D 6990-05. Standard practice for evaluating biofouling resistance and physical performance of marine coating systems; ASTM international: USA, 2005.

(30) ASTM D 153-84. Standard test methods for specific gravity pigments; ASTM international: USA, 2003.

(31) Killeffer, D.H., Linz, A. Molybdenum compounds. Their chemistry and technology; Inters-cience publishers: Easton: Pennsylvania, 1952.

(32) Persoone, G.; Jaspers, E.; Clasus, C. Ecotoxicological Testing for the marine environment. Proceedings of the International Symposium on Ecotoxicological Testing for the Marine Environment; Ghent, Belgium, 1983.

(33) Díaz, Baez, M.C.; Bulus, Rossini, G.D.; Pica, Granados, Y. Métodos estadísticos para el análisis de resultados de toxicidad. IDRC Books: Canada, 2004.

(34) Rascio,V.J.D., Giúdice, C.A., del Amo, B., Research and development on soluble matrix antifouling paints to be use on ships, offshore platforms and power station. A review. Corrosion Reviews, Vol. VIII, (1-2), 87-153 (1988).

(35) Yebra, D.M., Kiil , S., Dam-Johansen, K. Weinell, C.E., Reaction rate estimation of controlled-release antifouling paint binders: Rosin-based systems, Progress in Organic Coatings, (53) 256-275 (2005).

(36) Bellotti, N.; del Amo, B.; Romagnoli, R. Tara tannin a natural product with antifouling coating application. Prog. Org. Coat. 2012, 74, 411.

(37) Bastida, R.; Capezzani, A.; Torti, M.R. Fouling organisms in the port of Mar del Plata (Argentina). I.Siphonaria lessoni: ecological and biometric aspects. Mar. Biol, 1971, 10, 297. 
(38) Bastida, R.; Martin, J.P. La vida entre mareas: vegetales y animales de las costas de Mar del Plata. Mar del Plata; 1st ed. Publicaciones especiales INIDEP: Mar del Plata, 2004.

(39) Smith, B. Infrared Spectral Interpretation; 1st ed. CRC Press: New York, 1999.

(40) Cooper, J.W. Spectropic techniques for Organic Chemists; 1st ed. Wiley-Intercience Publication: USA, 1980.

(41) Morrison, R.T.; Boyd, R. N. Química Orgánica; Addison-Wesley Iberoamericana: Delaware, 1990. 
Table1. Composition of coatings as $\%$ of solids by volume

\begin{tabular}{|c|c|c|c|c|c|}
\hline \multirow{2}{*}{ Components } & \multicolumn{5}{|c|}{ Coatings } \\
\cline { 2 - 6 } & A & B & C & D & E \\
\hline QAT4 & 26.9 & 26.7 & 34.3 & ------ & ------ \\
\hline QAT8 & ------ & ----- & ----- & 26.9 & 26.7 \\
\hline Chalk & 17.9 & 17.7 & 8.7 & 17.9 & 17.7 \\
\hline WW rosin & 44.8 & 44.6 & 32.6 & 44.8 & 44.6 \\
\hline styrene-acrylate copolymer & ------ & ------ & 23.7 & ------ & ------ \\
\hline plasticized) & & & & & \\
\hline Oleic acid & 9.8 & 9,7 & ------ & 9.8 & 9.7 \\
\hline Castor oil & 0.6 & 0.6 & 0.7 & 0.6 & 0.6 \\
\hline ZnO & ------ & 0.7 & ----- & ------ & 0.7 \\
\hline
\end{tabular}




\section{Figures captions}

Figure 1. a) Basic chemical structure of "quebracho" tannin where R: OH or H; b) Chemical structure of the quaternary ammonium salt.

Figure 2. Chemical structure of : a) abietic acid; b) levopimaric acid

Figure 3. Precipitated amount of quaternary ammonium "tannate" (QAT 4 and QAT8) as a function of the amount of quaternary ammonium salt (QAS).

Figure 4. IR spectra of "quebracho" tannin (QT), the quaternary ammonium salt (QAS) and their derivatives (QAT4 and QAT8).

Figure 5. Accumulated amount of tannin leached from the coatings.

Figure 6. Tannin leaching rate from the different coatings.

Figure 7. Photographs of panels immersed in natural sea water environment. 
Figure 1.a)

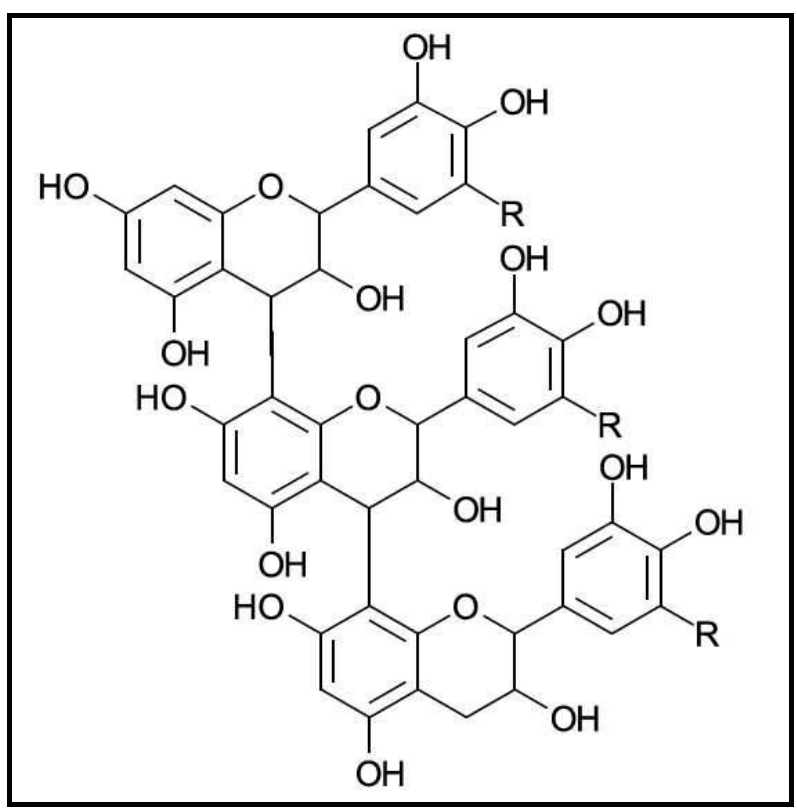

26

27

28

29

30

31

32

33

34

35

36

37

38

39

40

41

42

43

44

45

46

47

48

49

50

51

52

53

54

55

56

57

58

59

60 
Figure 1.b)

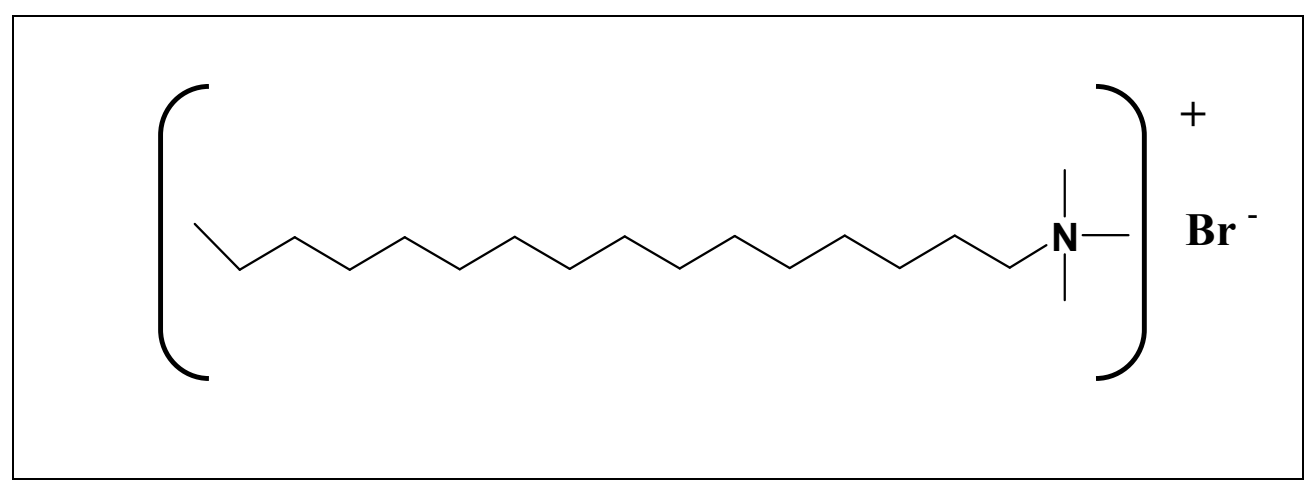

20

23

24

26

27

30

31

32

33

34

36

37

38

39

40

41

42

44

45

46

47

48

50

51

52

53

54

55

56

57

58

60 
Figure 2. a)

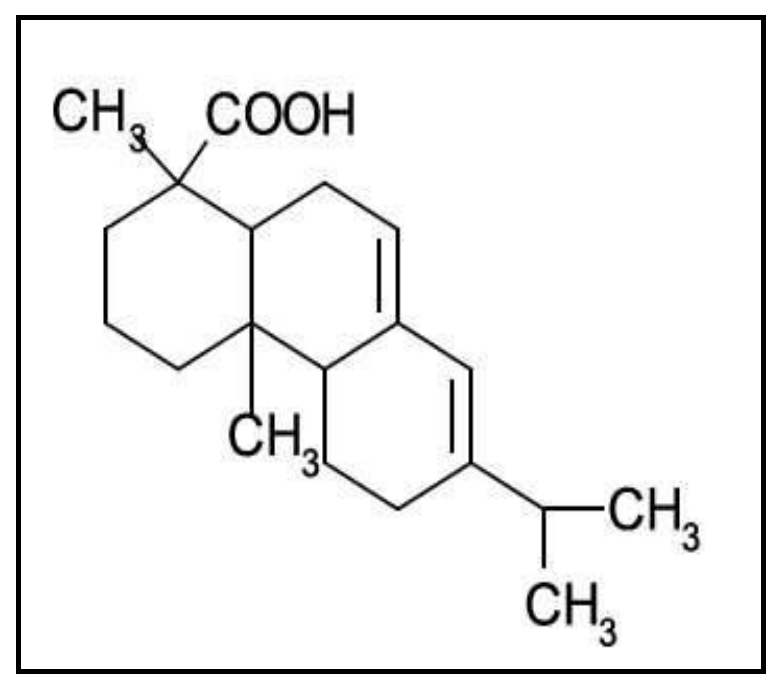


Figure 2.b)

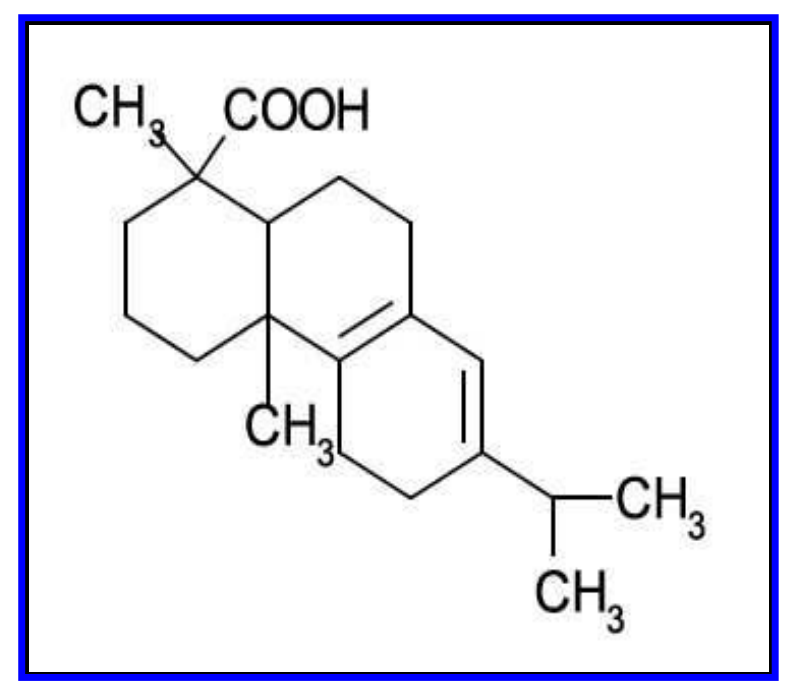


Figure 3

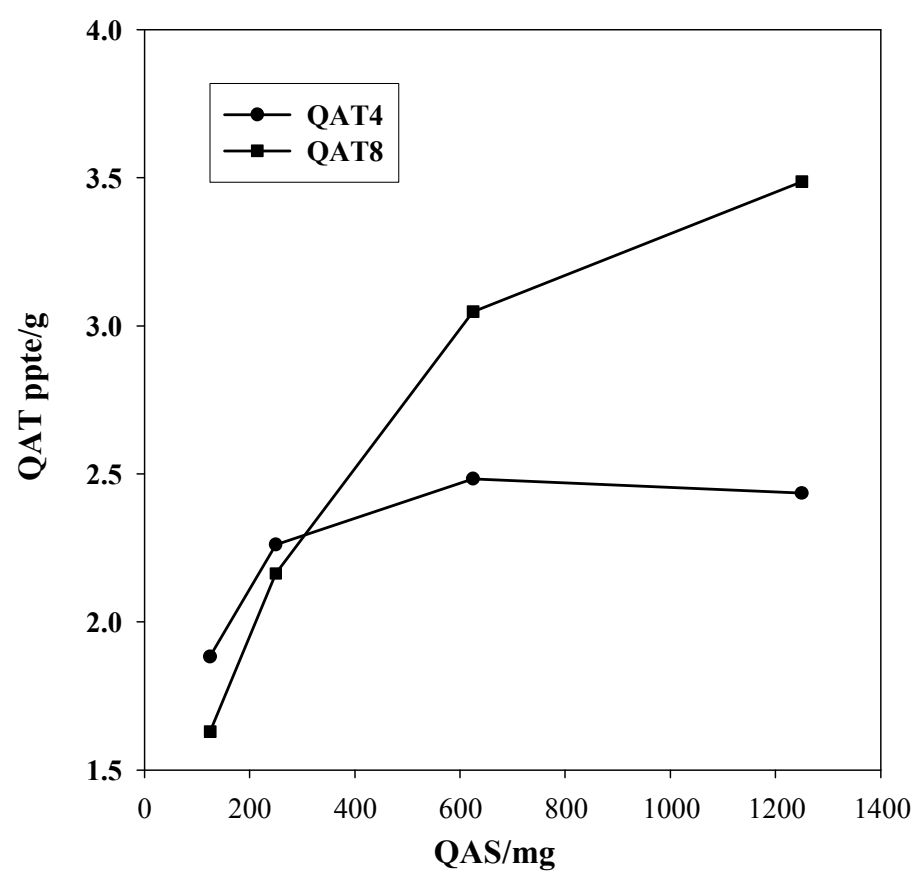


Figure 4

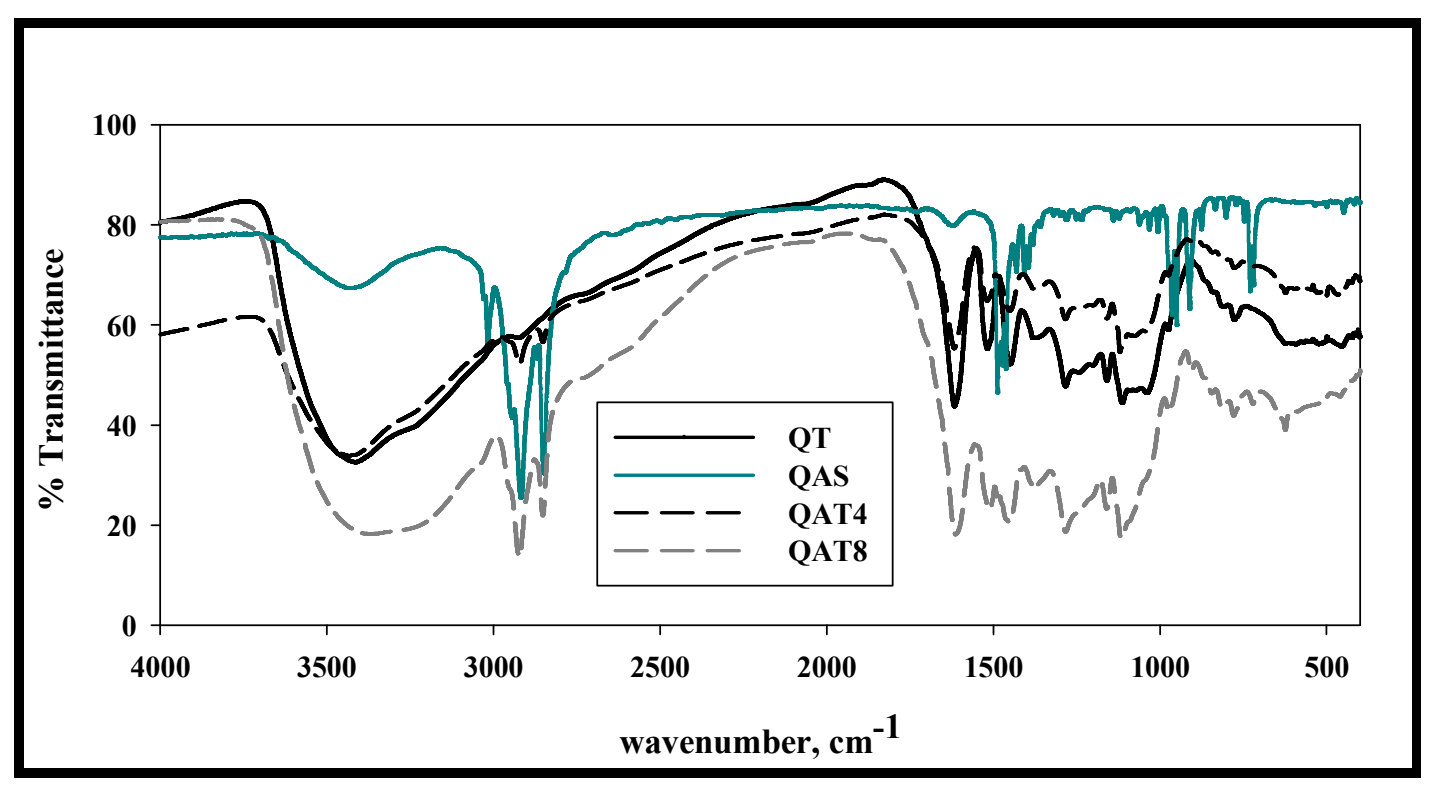




\section{Figure 5}

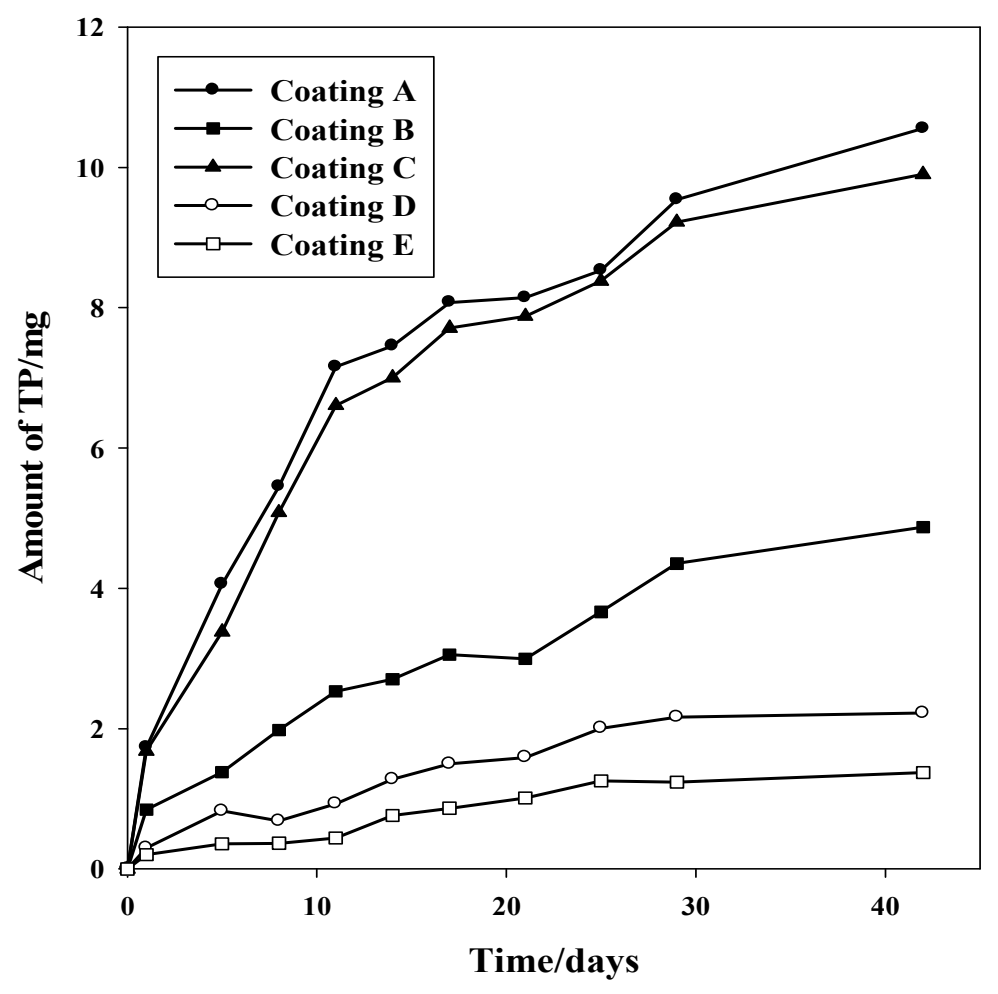


Figure 6

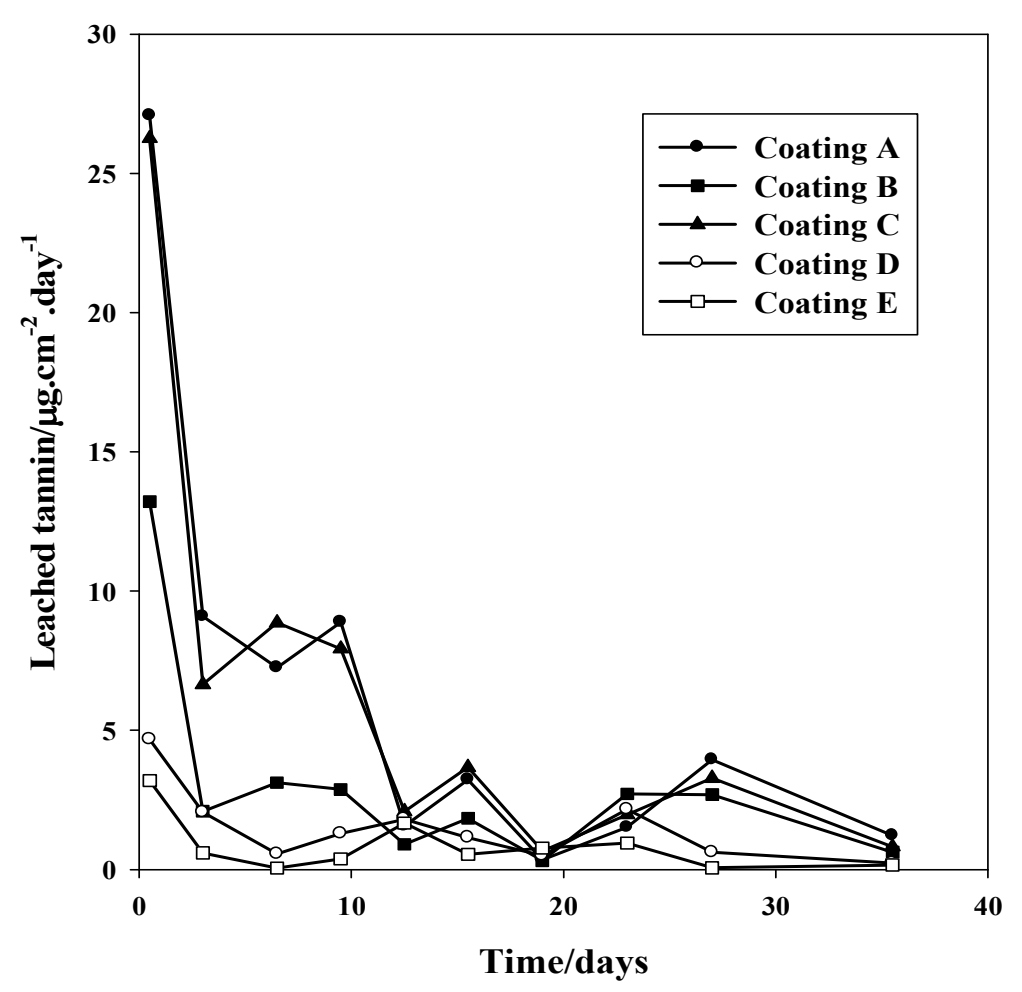


Figure 7

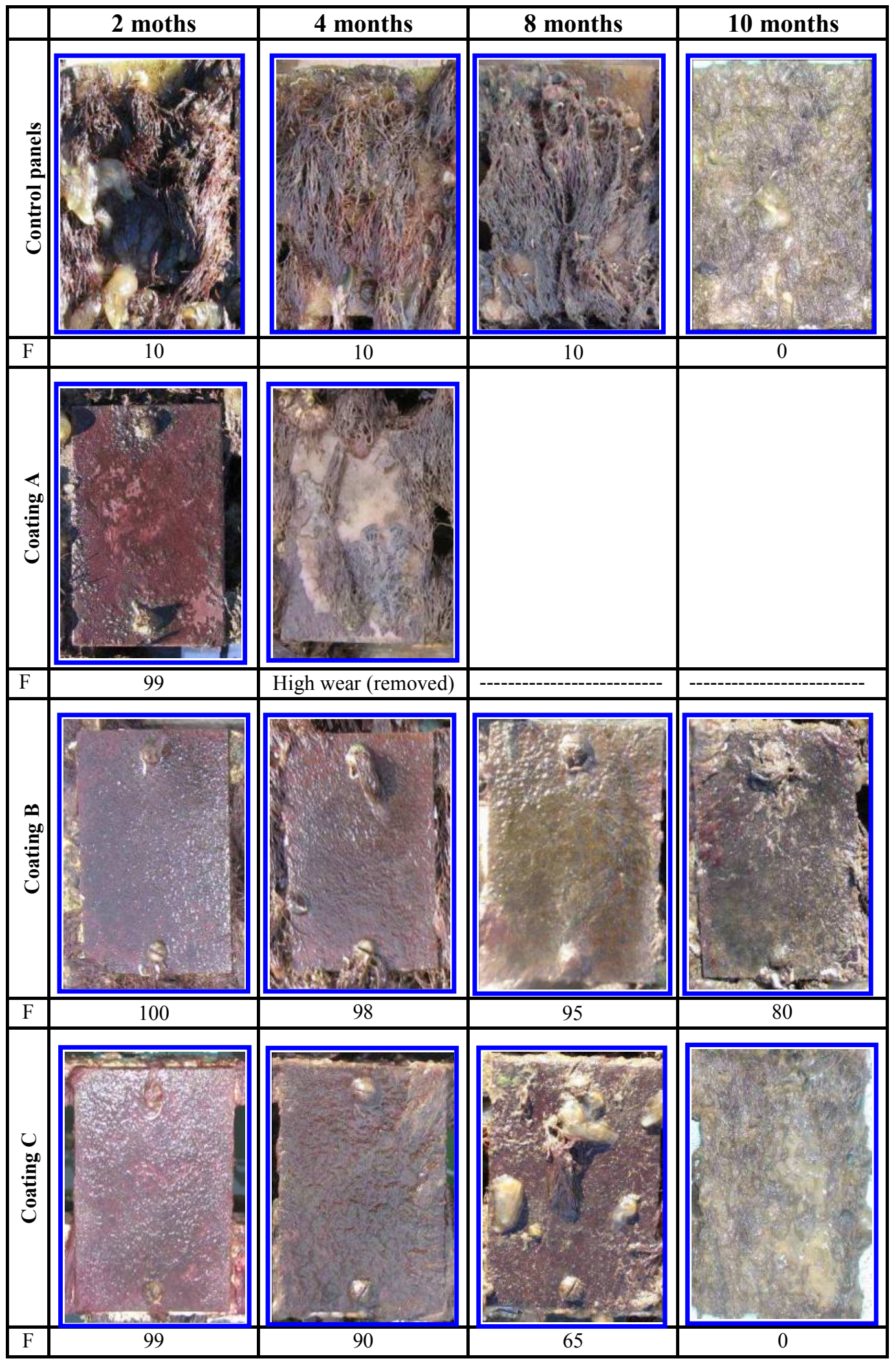

